\title{
Low birthweight infants: immediate feeding recalled
}

\author{
Pamela A Davies
}

The minutiae of low birthweight infant feeding rarely evoke unanimity among paediatricians. What to feed, how much of it to give, how to get it in, and what the long term effects might be, still occasion debate. The question of when to start after birth had its share of controversy nearly 30 years ago, and events leading to a change in practice are described.

The timing of the first feed was last reviewed here in $1978 .^{1}$ At the beginning of the century it was felt that feeding should begin as soon as possible after birth to prevent death from inanition. But for Julius Hess, an American physician renowned then for his pioneering care of low birthweight infants in Chicago, and an advocate of an early start, this meant giving nothing for the first 12 hours of life, and one to three feeds of human milk, obtained from a wet nurse if necessary, in the second 12 hours, 'if the infant's condition warrants'. ${ }^{2}$ The fear of aspiration of milk into the lungs was great. With feeble or absent sucking and swallowing reflexes in the most immature infants, and the tools for the job confined to spoon, pipette, or fountain pen filler, this is not surprising. However some 27 years later Hess was to counsel that the period of starvation for babies weighing less than $1200 \mathrm{~g}$ should be $24-48$ hours, subcutaneous injections of physiological saline being given in the interim. ${ }^{3}$ Mary Crosse, who started the first 'premature baby unit' in the United Kingdom, also changed her mind. In the first edition of The Premature Baby, published in 1945, she advised a 12 hour initial fast with dilute milk delayed to the third or fourth day. In the third, fourth, and fifth editions (the latter published in 1961) she advised that the first 24 96 hours should be without fluid of any kind. ${ }^{4}$

This was despite the fact that feeding techniques were advancing, for oesophageal gavage feeding with rubber tubes had been practised in the 1940s and plastic indwelling nasogastric tubes became available in the early 1950 s. And although two voices opposed the prolonged starvation period, 56 'scientific' rather than practical reasons for the delay were appearing. Clement Smith, noted for his work on the physiology of the newborn infant in Boston, Massachusetts, proposed in 1949 that as many low birthweight infants were oedematous and excreted large amounts of urinary sodium and potassium in first days of life, oedema would be increased and prolonged if solutions containing sodium were given. ${ }^{7}$ Smith was an influential voice in the United States and United King- dom. He had persuaded Gaisford and Schofield in Liverpool to impose further extremes of starvation, even up to 111 hours, ${ }^{8}$ and at a meeting in Finland disagreed with Yllpö, who believed starved babies became acidotic and should be given $5 \%$ glucose solution in the first 24 hours.

Hints of a change in attitude, however, were evident from 1960 onwards. In America Bauman reported a controlled trial in which preterm infants were given either $5 \%$ dextrose in $0.45 \%$ saline by nasogastric drip starting six hours after birth or nothing until the age of 36 hours, when both groups started milk feeds. Neither beneficial nor detrimental effects were recorded. ${ }^{9}$ Smith's group gave the same dextrose saline mixture early (within four hours of birth) to one group of infants of diabetic mothers, another being starved for 48 hours. While the incidence of hyaline membrane disease was unchanged, early feeding reduced indirect bilirubin concentrations, lessening the need for exchange transfusion. ${ }^{10}$ And in the United Kingdom Laurance and HutchinsonSmith also reported less jaundice among preterm infants fed early rather than late with undiluted breast milk. ${ }^{11}$ Clement Smith, in his Borden Award address in 1962 considered he had been wrong in 1949 to put oedema forward as a reason for delaying feeding; most preterm infants were not oedematous at birth, though various stresses such as cold might make them so. He believed feeding techniques were improving fast so that aspiration was less common. He still nevertheless felt that the low birthweight infant could manage without added energy initially as he considered the babies had enough stored glycogen and fat, and tissue protein available for catabolism, to prevent them dying of inanition. ${ }^{12}$

Victoria Smallpeice, clinical director of the paediatric department in the United Oxford Hospitals had felt increasingly uneasy about such a practice for some time. She argued that the nourishment afforded the fetus via the placenta was continuous and that it made little sense to stop supplying it abruptly at birth and over the period of highest mortality. She recalled that as a medical student she had been impressed with the then unorthodox views of one of her teachers: he believed the prolonged starvation imposed on patients with typhoid fever was harmful. He had not found that allowing them a relatively liberal diet had influenced the likelihood of perforation and if this did

occur they were in much better shape for 103c Clareadon Road Correspondence to: Dr Davies. 
surgery, which previously had a high mortality. She heard the professor of surgery at the Institute of Child Health, London-Andrew Wilkinson-speak at an international congress of paediatrics in Lisbon in 1962 on the metabolic costs of starvation in newborn infants undergoing surgery, and the reparative effect of early feeds of undiluted breast milk on this chemical chaos. This fitted in with McCance's concept of continued growth being all important in the maintenance of normal homoeostasis. ${ }^{13}$ These ideas excited her and she returned from the Lisbon meeting resolved to start feeding low birthweight infants very soon after birth with expressed undiluted human milk. Her colleague Hugh Ellis generously allowed all infants weighing $1000-2000 \mathrm{~g}$ born in or admitted to the Nuffield Maternity Home at the Radcliffe Infirmary to be under her care for a trial period. This started in November 1962 and continued until the end of March 1964, by which time 111 infants had been included. Eight of the original 119 of the stipulated weight range had to be excluded: two because of oesophageal atresia, one whose admission was delayed until the fourth day, and five during the early part of the trial who died within four hours of birth without being fed.

The babies were fed via an indwelling nasogastric polyvinyl tube and were given $60 \mathrm{ml} / \mathrm{kg}$ of undiluted human milk in the first 24 hours of life, $90 \mathrm{ml} / \mathrm{kg}$ on the second day, $120 \mathrm{ml} / \mathrm{kg}$ on the third, and $150 \mathrm{ml} / \mathrm{kg}$ on the fourth. That this break with traditional care was introduced with apparent ease was largely due to the enthusiasm and skill of the young nursing staff. The trial was uncontrolled, but comparison was made with the 45 infants of the same birthweight cared for at the Churchill Hospital, Oxford, over the same time period, by the same medical staff, but fed later. The early fed infants had lower mean serum bilirubin concentrations and passed their first meconium and regained birth weight at earlier mean times (all $p<0.05)$. Twenty seven of the $111(24 \%)$ early fed infants died, as did 12 of $45(27 \%)$ of the later fed.

The paediatric section of the Royal Society of Medicine held its summer meeting in Oxford in 1964 and these results were reported there. ${ }^{14}$ I think it is fair to say they were listened to with some interest, but doubt and scepticism were also evident. The results were later recorded in more detail in the Lancet, ${ }^{15}$ and a few months later an editorial there adopted a rather lofty tone of disapproval implying that any possible advantages were outweighed by the risks, and that if 'nature' had created the healthy mature human infant to observe 'temperance and moderation' over his first drink, then presumably she also knew best where the preterm infant was concerned. ${ }^{16}$ The nature argument did not cut much ice with Smallpeice and Davies who knew that many full term infants would suck avidly at the breast within a short time of birth given the chance, and who felt she was a poor model for the preterm infant, mortality in that situation being nearly $100 \%$. But was the Lancet editorial right about the risk? Perinatal mortality for infants weighing $1000-2000 \mathrm{~g}$ at the Radcliffe
Infirmary was lower in the single full year of the trial (1963) than in any year since records were first available there (1952), but this was not a controlled trial. Towards the end of 1965 Wharton and Bower published the results of such a trial undertaken at the Sorrento Maternity Hospital, Birmingham, the unit from which Mary Crosse had lately retired. A total of 239 infants were involved, alternate admissions being fed within two to eight hours (usually within two to four hours of birth) using volumes similar to those used at Oxford, the remainder being fed at 12 to 16 hours with much smaller amounts. The mortality in the early fed group was $17 \%$, and in the later fed group $6 \%$ $(p<0.01)$. When deaths considered inevitable or 'due to factors other than immediate feeding' were excluded, a substantial difference $(13.8 \%$ compared with $5 \cdot 8 \%$ ) remained but did not reach significance. ${ }^{17}$ Wharton and Bower reported that in some very preterm infants in the early fed group 'apnoeic attacks with cyanosis and circulatory failure were regularly occurring after each feed'; six of 20 infants who died in this group were considered to have aspirated feeds. Bilirubin concentrations were significantly lower and birth weight was regained significantly earlier in the immediately fed group ( $<<0.01$ for both). Symptomatic hypoglycaemia occurred in four of the later fed group, one of whom died, but in none of the early fed group. The authors reported they intended to continue early feeding with undiluted breast milk, but reduce the volumes by a third. In Oxford no change was made.

Appreciation of the concept of intrauterine growth retardation was fast gaining ground, and the tendency of these small for gestational age infants to have low blood glucose concentrations was becoming more widely understood. Experimental work too was suggesting that food restriction at a certain vulnerable period early in life might result in permanent stunting of organ and body size; this in turn being explained by what John Dobbing dubbed the cell number/ cell size hypothesis. ${ }^{18}$ It engendered a good deal of excitement at the time, particularly with regard to the growing brain, and caught up in this when following up low birthweight infants at Hammersmith Hospital later, I thought their later outcome might give some support for the experimental work.

Infants weighing less than $1500 \mathrm{~g}$ at birth cared for there between 1961 and 1964 had been given significantly less food in the first week, and had significantly lower body temperatures for the first four weeks of life than similar infants born in 1965 to $1968 .{ }^{19}$ Head circumference centiles of infants appropriately grown for gestational age showed a normal distribution in the latter four years, but were skewed to the left in the earlier period, as were those of small for gestational age infants throughout the entire eight years. This was interpreted thus: lower body temperatures consequent on the lower environmental temperatures imposed during 1961 to 1964 could mean that energy derived from food would have to be diverted to heat production instead of being available for growth, and infants appropriately grown at 
birth were being converted to growth retarded ones after birth by lack of warmth and food. The results were thought to give some support for the hypothesis that relatively minor undernutrition during a time of very rapid brain growth could result in a deficit in the ultimate size of the brain.

Some years later, but before being aware that the brain does not grow first by cell multiplication to an adult number followed by a later increase in cell size (the cell number/cell size hypothesis ${ }^{18}$ ), I felt the above conclusions were doubtful. The numbers were relatively small, the infants were cared for before cerebral ultrasonography was being applied in neonatal units, and.it seemed probable that not a few of the 'well grown' heads could be associated with ventricular dilatation as survival from intraventricular haemorrhage increased. Thus if there were benefits to be gained from reducing the period of starvation to as short a time as possible I believe they lay more in preventing symptomatic hypoglycaemia, reducing bilirubin concentrations and the need for exchange transfusion, and in allowing somatic growth to resume earlier, than in any important effect on brain growth.

Were there harmful effects of immediate feeding? The increased mortality of the alternate case trial at Birmingham has already been referred to; careful review of the Wharton and Bower paper led us to believe the verdict was not proved. But in any event both trials have been largely overtaken by the increasing survival of very immature babies, and a single regimen of feeding suitable for all low birthweight infants can no longer be prescribed. The larger numbers of infants with birth weights less than $1000 \mathrm{~g}$ now surviving was the spur for further research into their nutritional requirements. ${ }^{20}$ The skill and care with which young doctors and nurses developed parenteral feeding were in no small measure responsible for lowering mortality. Few would deny that it can occasionally have serious, even lethal, complications but used for short periods in the transitional stage after birth when respiratory illness is most likely it has proved invaluable. I resisted it for too long.

The arrival of numbers of cases of necrotising enterocolitis in neonatal intensive care units some $\mathbf{2 0}$ or more years ago gave me considerable concern as I wondered if it could have been associated with immediate and liberal enteral feeding. The condition has been recognised in sporadic case reports since the end of the last century and has now been described in infants never fed or fed only intravenously. Its dramatic impact coincided with a period of rapidly falling mortality among low birthweight infants so that the new breed of very immature, often sick babies were at risk from a condition whose salient features seem to be a disturbance both of the integrity of the intestinal mucosa, and of bowel flora (often altered by antimicrobial drugs), allowing certain bacteria to multiply to critical levels. It is still possible that like its near relative of adult life, pseudomembranous colitis/ antibiotic associated diarrhoea, certain bacterial toxins will ultimately be found to have a decisive role. The occasional clustering of cases in neonatal units suggests infection may be impor- tant. Early feeding with breast milk as practised by us on balance is unlikely to have been causal. But just as starvation was sometimes carried to extremes, I think it was sometimes followed in the 1970 s by a certain immoderate liberality of both enteral and parenteral fluid. For a condition whose aetiology is clearly multifactorial, a cautious graduated approach to total intake in those at particular risk seems wise.

Drillien recorded particularly poor results at follow up of low birthweight children in Edinburgh in two years (1953 and 1954) when fluid had been witheld completely for the first three to four days of life there, milk not being introduced until the fifth to ninth days, a truly spartan regimen. ${ }^{21}$ While no one to day would venture feeding breast milk within an hour or two of birth to a $500 \mathrm{~g}$ infant, I think it is unlikely that those of low birthweight will ever again be starved as they largely were when Victoria Smallpeice-with vision and not a little courage-inaugurated her trial of early feeding with human milk in 1962 . Her belief that their nutrition should be interrupted as briefly as possible so that growth could be resumed soon after birth is likely to endure. If the benefits of her work have been difficult to measure with precision because of a rapidly changing neonatal scene, I do believe them to be real. I was privileged to work with her in those days and learned many lessons from my involvement with early feeding.

Dr Victoria Smallpeice will I hope celebrate her 90th birthday this year. I am greatly indebted to her for going over old ground again with me for this article and for her continuing keen interest in, and critical discussion of matters neonatal since her retirement in 1966 .

1 Davies DP. The first feed of low birthweight infants. Chang ing attitudes in the twentieth century. Arch Dis Child 1978;53:187-92.

2 Hess JH. Premature and congenitally diseased infants. Philadelphia: Lea and Febiger, 1922:179.

3 Hess JH, Lundeen EC. The premature infant. Medical and nursing care. Philadelphia: JB Lippincott Company, 1949:115.

4 Crosse VM. The premature baby. London: J and A Churchill, 1945:42-72. (3rd ed 1952, 4th ed 1957, 5th ed 1961.)

5 Yllpö A. Premature children. Should they fast or be fed in the first days of life. Annales Paediatriae Fenniae 1954-55;1: 99-104.

6 Gleiss J. Zum Frühgeborenenproblem der Gegenwart. 1X. Mitteilung. Uber futterungs-und umweltbedingte Atemstörungen bei Frühgeborenen. Zentralblatt Kinderheilkunde störungen bei F

7 Smith CA, Yudkin S, Young W, Minkowski A, Cushman M. Adjustment of electrolytes and water following premature birth (with special reference to edema). Pediatrics 1949;3:34-48.

8 Gaisford $W$, Schofield S. Prolongation of the initial starvation period in premature infants. $B M \mathcal{F}$ 1950;i:1404-5.

9 Bauman WA. Early feeing of dextrose and saline solution to premature infants. Pediatrics 1960;26:756-61.

10 Hubbell JP, Drorbaugh JE, Rudolph AJ, Auld PAM, Cherry RB, Smith CA. 'Early' versus 'late' feeding of infants of diabetic mothers. $N$ Engl $\mathcal{Y}$ Med 1961;265:835-7.

11 Laurance BM, Hutchinson-Smith B. The premature baby's diet. Lancet 1962;i:589-90.

12 Smith CA. Prenatal and neonatal nutrition. Borden Award address. Pediatrics 1962;30:145-56.

13 McCance RA. The maintenance of stability in the newly born. 1. Chemical exchange. Arch Dis Child 1959;34: 361-70.

14 Smallpeice V, Davies PA. The immediate feeding of babies weighing $1,000-2,000 \mathrm{~g}$ with breast milk. Proceedings of the Royal Society of Medicine 1964;57:1173-5.

15 Smallpeice V, Davies PA. Immediate feeding of premature infants with undiluted breast-milk. Lancet 1964;ii:1349-52. infants with undiluted breast-milk. Lancet 1964;ii:1349-52. 791-2.

17 Wharton BA, Bower BD. Immediate or later feeding for premature babies? A controlled trial. Lancet 1965;ii:969-72. Dobbing J. Infant nutrition and later achievement. Nutr Rev 1984;42:1-7.

19 Davies PA, Davis JP. Very low birth-weight and subsequent head growth. Lancet 1970;ii:1216-9.

20 Shaw JCL. Growth and nutrition of the very preterm infant. Br Med Bull 1988;44:984-1009.

21 Drillien CM. The growth and development of the prematurely born infant. Edinburgh: E and S Livingstone, 1964:302-8. 